\title{
THE MAIN TERMINOLOGICAL DISADVANTAGES OF THE CURRENT LEGISLATION OF UKRAINE AND THE PROPOSALS FOR THEIR ABOLITION
}

\author{
Oleksandra Khrishcheva ${ }^{1}$ \\ Svitlana Formanova ${ }^{2}$
}

DOI: https://doi.org/10.30525/978-9934-588-39-6-20

After Ukraine regained its independence, the necessity of legal terminology on a national basis was appeared.

Reforming the legal system of Ukraine actualizes the importance of upgrading the current legislation, its harmonization with legal system of EU member States, explains changes of priorities of law-making process and as a result improvement of legal terminology of general acts.

Effective enforcement of laws (as well as secondary legislation) is based on the accuracy of the legal rules contained therein, which should be terminologically literate and set out in clear and available language.

It should be noted that, to date, unfortunately, the terminology of Ukrainian legislation doesn't fully comply with the statutory requirements that are set for legal terms.

The main terminological shortcomings of the current legislation of Ukraine include:

1. The existence of polysemantic (multi-valued) words in the texts of legal acts.

For example, the meaning of the term «work» is used in the norms of the Labor Code of Ukraine in several meanings: as a production activity (Article 60), as a work function (Article 107), and also as a place of work (Article 187) [1]. Because of this, in some cases, it may be difficult to determine the meaning that the legislator has put into legal rule, using the word «work».

The existence of several different legislative definitions in the term leads to unclear legal regulation, giving rise to misunderstandings, errors and conflicts of law.

2. Use of synonyms in the text of legal acts.

For example, in the Criminal Code of Ukraine in different norms the legislator uses such synonyms: «incitiment» (Article 323), «inducement» (Articles 315, 324), «involvement» (Articles 303, 304), «engagement» (Articles 307, 317 CC), etc. [2].

\footnotetext{
${ }^{1}$ I.I. Mechnikov National University, Ukraine

${ }^{2}$ I.I. Mechnikov National University, Ukraine
} 
3. Using in text of laws and by-laws the same terms for the name of different concepts.

4. Using in the text of regulatory documentation excessive number of foreign language terms.

Integration processes, harmonization of legislation leads to the saturation of the Ukrainian legal terminology with foreign language terms. Therefore, the use of foreign language terms in the texts of legislative acts is a natural phenomenon. But despite this, the legislator should not allow unjustified internationalization of Ukrainian terminology.

5. Absence of definitions of legal concepts in the texts of legal acts.

6. Excessive amount of terms that denote evaluative concepts (fairness, reasonable periods of time, etc.) in the texts of normative legal acts.

7. The use of tautological structures.

For example, the Criminal Code of Ukraine contains the term «blackmail» (Articles 120, 149, 303), which has no legal definition [2]. That is why, both in the science of criminal law and in practice, this concept has different meanings.

6. Excessive number of terms, which denoting valuation concepts in the texts of legal acts (fairness, reasonable terms, etc.).

7. Using of tautological structures.

In current Ukrainian legislation, the use of the tautological structures like «damage compensation» or «security» is quite common.

To date, the terminological techniques of legal technology regulate these by-laws: methodological recommendations of the Apparatus of the Verkhovna Rada of Ukraine «Rules for processing of draft laws and basic requirements of legislative technology», «Rules for preparation of draft laws of the Cabinet of Ministers of Ukraine» № 870, approved by the Cabinet of Ministers Decree dated 6 september 2005 and others.

However, there is no single systemic document that would set requirements for the content, structure, features of the formulation of legal norms and constructions in draft regulatory acts, regardless of the entity preparing the project.

We support the view that in order to abolish the terminological problem in Ukraine a single (common for linguists and jurists) state scientific center of legal terminology problems should be established, as well as the National Terminological Commission for expert evaluation of terminology of current legislation and draft laws, development of methodology of terminological examination of legal acts and other documents.

We think that more attention should be paid to developing of methodological program of the Ukrainian language for professional orientation course for future lawyers, who studying in higher education 
institutions, in order to form in them more successful language culture and terminological competence.

More hours should be spent to study the topic «Legal Terminology» or to enter a separate interdisciplinary course, within which to study: problems of synonymy, disambiguation and polysemy of legal terms, ways of their solution; the process of formation, development and improvement of legal terminology etc.

We share the opinion of N.V. Articutca about the necessity to create specialized courses of legal terminology for legal creators, civil servants, compilers of legal dictionaries, editors of legal literature, translators of legal texts, scientists-researchers of legal terminology in different directions [3, p. 10].

More attention should be paid to the creation of legal terms on a national basis rather than to borrowing them from foreign languages.

The risk of law-making mistakes will be significantly reduced if the preparation of draft laws is carried out in accordance with the requirements of legal technique and the requirements of formal logic, based on the norms of modern Ukrainian literary language.

\section{References:}

1. Kodeks zakoniv pro pracju Ukrainy: Zakon Ukrainy vid 10.12.1971 p. № 322-VIII zi zminamy ta dopovnennjamy vid 12.12.2019 r. URL: https://zakon.rada.gov.ua

2. Kryminalnyj kodeks Ukrainy: Zakon Ukrainy vid 05.04.2001 r. № 2341-III (zi zminamy ta dopovnennjamy vid 20.12.2019 r. URL: https://zakon.rada.gov.ua

3. Artykuca, N. V. (2004). Mova prava i jurydychna terminologhija [Language of law and legal terminology]. Kiev: Stylos. (in Ukrainian) 